Annals of International Medical and Dental Research

E-ISSN: 2395-2822 | P-ISSN: 2395-2814

Vol-8, Issue-1 | January-February 2022

DOI: $10.53339 /$ aimdr.2022.8.1.40

Page no- 318-324 | Section- Research Article (Paediatrics)

\title{
Clinico-Epidemioogical and Radiological Profile of Broncholitis at Sher-E-Bangla Medical College Hospital in Barishal, Bangladesh
}

\section{Ashis Kumar Halder ${ }^{*}$, Syeeda Sultana², Bikash Chandra Nag ${ }^{3}$, Md. Mahabub Alam, Mehdi Pervez $^{5}$, Mohammad Faisal Hasan Bhuiyan ${ }^{6}$, Tajmira Nasrin ${ }^{7}$}

${ }^{1}$ Assistant Professor, Department of Paediatrics, SherE-Bangla Medical College, Barishal, Bangladesh. Email: drahalder@gmail.com

Orcid id: 0000-0003-2585-3301

${ }^{2}$ Assistant Professor, Department of Gynecology and Obstetrics, Sher-E-Bangla Medical College, Barishal, Bangladesh.

Email: sultanasyeeda9@gmail.com

Orcid id: 0000-0001-7766-3222

${ }^{3}$ Assistant Professor, Department of Paediatrics, SherE-Bangla Medical College, Barishal, Bangladesh. Email: dr.bcnag@gmail.com

Orcid id: 0000-0002-3268-1694

4Lecturer, Department of Pathology, Sher-E-Bangla Medical College, Barishal, Bangladesh.

Email: mahabubrajon86@gmail.com

Orcid id: 0000-0002-1955-3532

${ }^{5}$ Assistant Registrar, Department of Paediatrics, SherE-Bangla Medical College Hospital, Barishal, Bangladesh.

Email: lonerider58@gmail.com

Orcid id: 0000-0001-9863-0550.

${ }^{6}$ Registrar, Department of Paediatrics, Sher-E-Bangla

Medical College Hospital, Barishal, Bangladesh.

Email faisaldc38@gmail.com

Orcid id: 0000-0002-5613-1742

${ }^{7}$ Medical officer, Outpatient Department, Sher-E-

Bangla Medical College Hospital, Barishal,

Bangladesh.

Email: tajmirak60@gmail.com

Orcid id: 0000-0002-8300-6445

*Corresponding author

Received: 16 September 2021

Revised: 09 Novmber 2021

Accepted: 19 November 2021

Published: 22 December 2021

\section{Abstract}

Background: Bronchiolitis, caused mostly by Respiratory syncytial virus (RSV) virus is the leading cause of lower respiratory tract infection in infants. The disease is mostly presents with cough runny nose, fever, breathing difficulties and respiratory failure This infection usually affects children up to age of 24 months, with younger infants often more severely affected and is the most prevalent cause of hospitalization in infants under the age of 12 months. The treatment is supportive; therefore, epidemiology, clinical, laboratory, and radiologic findings can help to ensure appropriate diagnosis and proper treatment. Methods: This descriptive cross-sectional observation study was conducted at Paediatrics department of Sher-E-Bangla Medical College \& Hospital (SBMCH), Barishal, Bangladesh between October 2018 to March 2019 To find out the clinicoepidemiological and radiological profile of Bronchiolitis. Children below 24 months of age diagnosed as bronchiolitis were studied. Results: 200 children were evaluated, including 150 boys and 50 girls; Infants below 6 months accounted for the highest proportion (60\%). All the bronchiolitis patients had cough or cold with respiratory distress. Other symptoms were fever $(98.0 \%)$, restlessness $(63.0 \%)$, poor feeding $(60 \%)$ and fast breathing. On examination lower chest indrawing and rhonchi were found in all cases. Hyperinflation was the most prevalent radiological finding $(60 \%)$ and more than half $(55 \%)$ patients had lymphocytosis on CBC. Conclusion: Most children present with typical clinical and radiological feature of bronchiolitis which can help the clinicians to clinically identify this disease more efficiently.

Keywords:- Bronchiolitis. Respiratory syncytial virus, wheezing. 
Annals of International Medical and Dental Research

E-ISSN: 2395-2822 | P-ISSN: 2395-2814

Vol-8, Issue-1 | January-February 2022

DOI: $10.53339 /$ aimdr.2022.8.1.40

Page no- 318-324 | Section- Research Article (Paediatrics)

\section{INTRODUCTION}

Bronchiolitis is a lower respiratory tract infection characterized by obstruction of small airways caused by acute inflammation, edema and necrosis of the epithelial cells lining the small airways as well as increased mucus production and bronchospasm.[1] Bronchiolitis most commonly presents in infants aged three to six months. It occurs in association with viral infections (respiratory syncytial virus; RSV, in, around $50 \%$ of cases) and is seasonal. Many viruses cause the same constellation of symptoms and signs. $[2,3]$ The most common etiology is the respiratory syncytial virus (RSV) with the highest incidence between December and March. Ninety percent of children are infected with RSV in the first 2 years of life and up-to $40 \%$ of them will have lower respiratory infection. Infection with RSV does not grant permanent or long term immunity. Re $\neg$ infections are common and may be experienced throughout life. Other organisms causing bronchiolitis are human metapneumovirus (HMPV), influenza, adenovirus, parainfluenza, rhinovirus, enteroviruses, herpes simplex, mumps virus and mycoplasma pneumonae.4] Bronchiolitis caused by RSV infection can manifest itself in a number of ways, ranging from moderate upper respiratory tract infections to severe and possibly life-threatening lower respiratory tract infections requiring hospitalization and mechanical ventilation. $[5]$ By the age of two, the majority of children will have had at least one RSV infection.6] While most acute bronchiolitis cases are mild and can be cured by home treatment, $[7,8]$ acute respiratory distress syndrome causes $2-3 \%$ of pediatric patients to be admitted to hospitals, with $5 \%$ of them requiring transfer to intensive care units. It is imperative to have the Knowledge regarding the patient's age, gender, presenting signs and symptoms to identify and properly manage bronchiolitis as a clinical syndrome in everyday practice. With the above scenario, we propose to explore the epidemiological and clinical characteristics of acute bronchiolitis presenting at the Department of Pediatrics, Sher-E-Bangla Medical College Hospital, Barishal, a southern medical college hospital of Bangladesh, between October 2018 to March 2019.

\section{MATERIAL AND METHODS}

This descriptive cross-sectional observation study was conducted at Pediatrics department of Sher-E-Bangla Medical College \& Hospital (SBMCH), Barishal between October 2018 to March 2019. A total of 200 cases were studied, study population included children below 2 years of age. Consecutive cases of newly diagnosed bronchiolitis patients below two years of age, attending paediatric inpatient and outpatient department during the study period with the complaints of cough, sneezing, rhinorrhea progressing to lower chest in drawing and/or fast breathing were included as study cases. The inclusion criteria were developed on the basis of National guidelines for the management of bronchiolitis. ${ }^{8]}$ Those with chronic neurologic, renal, heart, or lung disease and patients with immune deficiency were excluded.

Data on clinical parameters and demographic factors were collected with a predetermined structured data collecting instrument. After taking proper written consent of parents, the questionnaire was filled up through face to 
Annals of International Medical and Dental Research

E-ISSN: 2395-2822 | P-ISSN: 2395-2814

Vol-8, Issue-1 | January-February 2022

DOI: $10.53339 /$ aimdr.2022.8.1.40

Page no- 318-324 | Section- Research Article (Paediatrics)

face interview. Clinical examination was done meticulously in all cases. Complete blood count \& chest radiograph were also obtained. After collection of data, they were edited through checking and rechecking. Data analysis was being done by computer aided statistical software Statistical Package for Social Sciences version 22.0 for Windows (SPSS Inc., Chicago, Illinois, USA). Data was presented in form of tables and graphs.

\section{RESULTS}

There were 200 children from 1 to 24 months of age admitted to Department of Pediatrics of Sher-E-Bangla Medical College \& Hospital (SBMCH), Barishal between October 2018 to March 2019. Table 1 shows the socio-economic background from which the subjects of both group came. Most of the children reside in the rural area $(81.0 \%)$. Majority $(58.0 \%)$ of the cases belongs to low income group (monthly income Tk. 5000 or less). Table 2 depicts the epidemiological features of all studied patients. Among the patients, 150 (75\%) were males, and $50(25 \%)$ were females. All children evaluated during the research are divided into four groups based on the age distribution of bronchiolitis incidence. Children under the age of 6 months made up the first group, children aged 6 to less than 12 months made up the second group, children aged 12 to less than 18 months made up the third group, and children aged 18 to 24 months made up the fourth group. In our study, there were 120 (60\%) children in the first group, $32(16 \%)$ children in the second group, 18(9\%) children in the third group, and $10(5 \%)$ children in the fourth group. Figure 1 shows that all the bronchiolitis patients had cough or cold with respiratory distress. Other symptoms were fever (98.0\%), restlessness $(63.0 \%)$, poor feeding $(60 \%)$, runny nose $(57.0 \%)$ and blocked nose $(17.0 \%)$. The physical findings elicited in the studied cases were fast breathing $(100 \%)$, lower chest indrawing $(100 \%)$, wheeze or rhonchi $(100 \%)$, palpable spleen $(45 \%)$, enlarged liver $(38.0 \%)$ and crepitations (25\%). (Figure 2) Radiological findings observed in studied cases were shown in table 4. It shows most patients had hyperinflation on chest X-ray (60\%). Other common findings are increased translucency $(41.0 \%)$, streaky densities $(13.0 \%)$, patchy opacities (5\%), and collapse (3.0\%). No abnormalities on CXR were found in $17.0 \%$ cases. CBC revealed lymphocytosis in 110 patients (55\%), Leukopenia in 70 (35\%) cases and others had nor $\neg$ mal results in CBC (10\%) (Figure 3).

Table 1: Socio-economics profile of both cases and control $(\mathrm{N}=200)$.

\begin{tabular}{|l|l|}
\hline Parameters & Cases $(\mathbf{n}=\mathbf{2 0 0})$ \\
\hline Schooling of fathers of year (Mean \pm SD) & $8.9 \pm 4.9$ \\
\hline Schooling of mothers of year (Mean \pm SD) & $8.5 \pm 4.2$ \\
\hline Profession of father's & \\
\hline Service & $39.0 \%$ \\
\hline Business & $18.0 \%$ \\
\hline Farmer & $10.0 \%$ \\
\hline Others & $33.0 \%$ \\
\hline
\end{tabular}


Annals of International Medical and Dental Research

E-ISSN: 2395-2822 | P-ISSN: 2395-2814

Vol-8, Issue-1 | January-February 2022

DOI: 10.53339/aimdr.2022.8.1.40

Page no- 318-324 | Section- Research Article (Paediatrics)

\begin{tabular}{|l|l|}
\hline Professional of mother's & \\
\hline Housewife & $88.0 \%$ \\
\hline Others & $12 \%$ \\
\hline Monthly family income & \\
\hline Tk. 5000 or less & $25.0 \%$ \\
\hline Tk. 5001-10000 & $63.0 \%$ \\
\hline >Tk. 10000 & $12.0 \%$ \\
\hline Residence & \\
\hline Rural & $43.0 \%$ \\
\hline Urban & $47.0 \%$ \\
\hline Urban slum & $10.0 \%$ \\
\hline
\end{tabular}

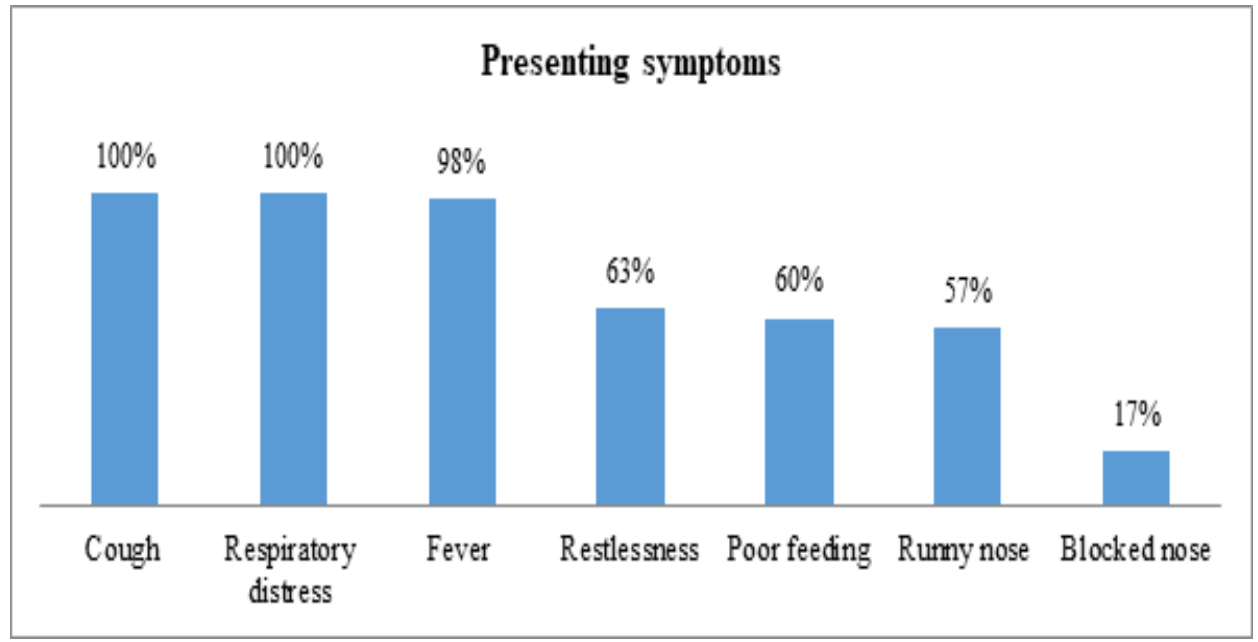

Figure 1: Symptoms in studied cases $(n=200)$

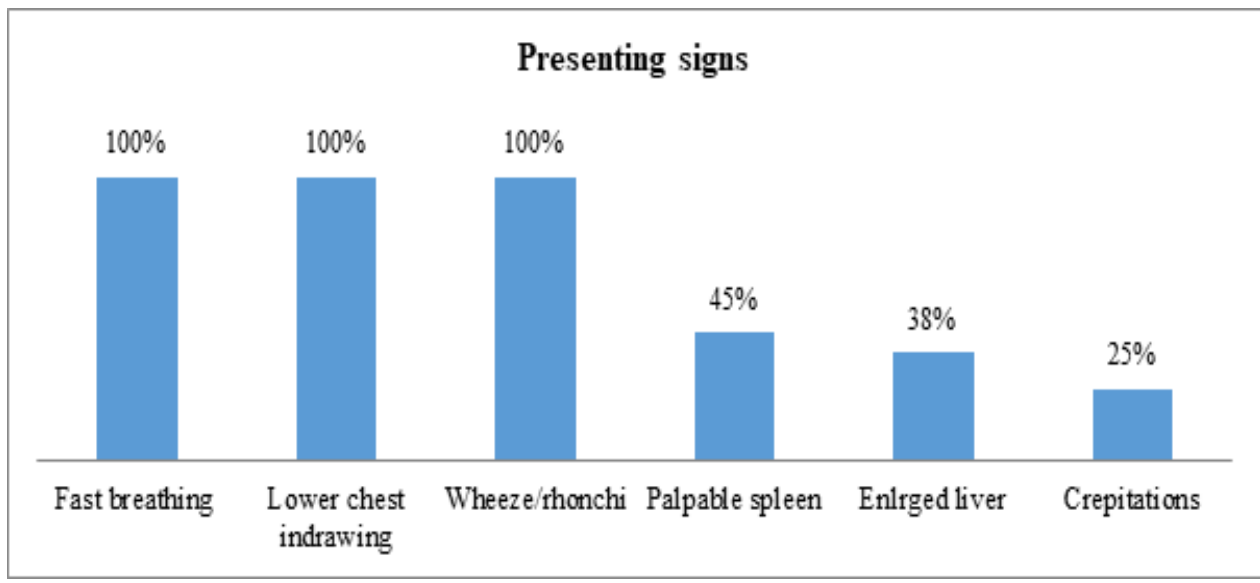

Figure 2: Signs in studied cases $(n=200)$ 
Annals of International Medical and Dental Research

E-ISSN: 2395-2822 | P-ISSN: 2395-2814

Vol-8, Issue-1 | January-February 2022

DOI: $10.53339 /$ aimdr.2022.8.1.40

Page no- 318-324 | Section- Research Article (Paediatrics)

Table 2: Sex distribution of the studied cases $(n=200)$.

\begin{tabular}{|l|l|l|l|}
\hline Sex & Number & Percentage & Ratio \\
\hline Male & 150 & $75.0 \%$ & $3: 1$ \\
\cline { 1 - 2 } Female & 50 & $25.0 \%$ & \\
\cline { 1 - 2 }
\end{tabular}

Table 3: Age distribution of the studied cases $(n=200)$.

\begin{tabular}{|l|l|l|}
\hline Age in months & Number & Percentage \\
\hline$\leq 6$ & 120 & 60 \\
\hline $7-11$ & 32 & 16 \\
\hline $12-17$ & 18 & 9 \\
\hline $18-24$ & 10 & 5 \\
\hline
\end{tabular}

Table 4: Radiological findings in studied cases $(n=200)$

\begin{tabular}{|l|l|l|}
\hline Findings & Number & Percent \\
\hline Hyperinflation & 120 & 60.0 \\
\hline Increased translucency & 82 & 41.0 \\
\hline Streaky densities & 26 & 13.0 \\
\hline Consolidation & 20 & 10.0 \\
\hline Collapse & 6 & 3.0 \\
\hline Patchy opacities & 10 & 5.0 \\
\hline Normal & 34 & 17.0 \\
\hline
\end{tabular}

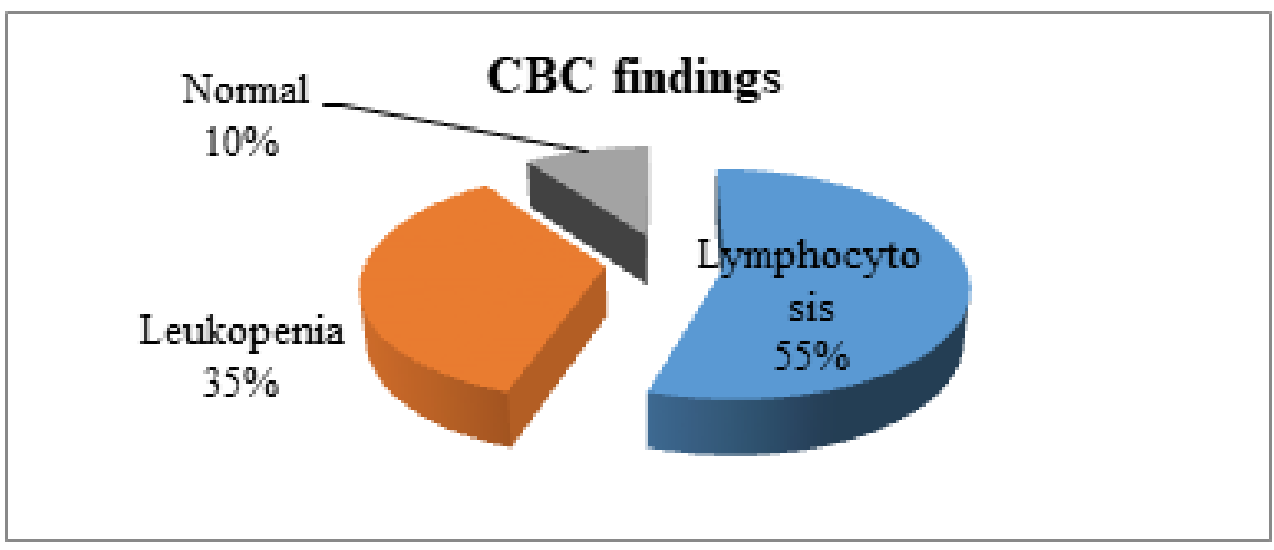

Figure 3: CBC findings in studied cases $(n=200)$

\section{DISCUSSION}

This cross-sectional observation study was conducted at Paediatrics department of Sher-EBangla Medical College \& Hospital (SBMCH), Barishal between October 2018 to March 2019.
A total of 200 cases were studied, study population included children below 2 years of age. Children under the age of 12 months were the most common age group of patients hospitalized with bronchiolitis, with children under the age of 6 months being the most 
Annals of International Medical and Dental Research

E-ISSN: 2395-2822 | P-ISSN: 2395-2814

Vol-8, Issue-1 | January-February 2022

DOI: $10.53339 /$ aimdr.2022.8.1.40

Page no- 318-324 | Section- Research Article (Paediatrics)

prevalent. It is shown in our study that that most of the cases are less than 6 months old which is in concordance with the findings of previous studies. $\frac{[9,10,11,12]}{\text { Table }} 3$ shows definite male preponderance among the case group with a male female ratio $2: 1$, which is in concordance with the previous findings that male children are always more vulnerable to develop bronchiolitis than female peers as observed in other studies. $\frac{[13,14,15,16,17,18,19]}{} \mathrm{We}$ have found that there were usual presentations of bronchiolitis where cough and runny nose are the main symptoms and rhonchi and lower chest in drawing are the principal examination findings. Nguyen et al found that that wheezing was the most frequent symptom when patients were hospitalized, accounting for $261(69.2 \%)$ of all patients, whereas wheezing and fever were the least common, accounting for $11(2.9 \%)$ of all patients. Clinical symptoms and signs such as wheezing, labored breathing, tachycardia, and sibilant rales were present in virtually every pediatric patient with acute bronchiolitis, especially tachypnea, runny nose, and cough was seen in $100 \%$ of patients. 19$]$ Singh et al found in a 2021 study in North India that the most common symptom in bronchiolitis was respiratory distress $(100 \%)$ followed by cough $(100 \%)$, fever $(85 \%)$, cold $(75 \%)$, nasal discharge $(75 \%)$, vomiting in $(40 \%)$. 20$]$ Soleimani et al found in 2014 that the most common clinical signs were cough $(89 \%)$, wheezing $(79 \%)$, rhinorrhea $(73 \%)$, fever $(72 \%)$, and dyspnea (71\%), consecutively. In radiologic studies, hyperinflation was the most prevalent finding. 21$]$ Table 4 shows that the most common radiological findings in the study subjects were increased translucency and hyperinflation which is consistent with the findings of Farid et al.222] Soleimani et al found in 2014 that in radiologic studies, hyperinflation was the most prevalent finding. 21$]$ Nguyen et al found that $32.9 \%$ cases presented features of air trapping in the lungs. 19] Lymphocytosis in 110 patients (55\%), Leukopenia in $70(35 \%)$ cases and others had normal results in CBC $(10 \%)$ (Figure 3). In their study Soleimani et al reported Lymphocytosis in 67 patients (67\%) and all others had normal results in CBC (33\%). [19] Finally, the correct diagnosis of bronchiolitis can be made by considering the most common epidemiological factors such as age, gender, clinical findings laboratory and radiologic signs, and therefore ensuring proper diagnosis and appropriate treatment.

\section{Limitations of the study}

The study had a too small sample size. The study was conducted in a single center which doesn't reflect the original scenario of Bangladesh. So here need a large multi scale, multi center countrywide study for authentic outcome.

\section{CONCLUSIONS}

Most children present with typical clinical and radiological feature of bronchiolitis which can help the clinicians to clinically identify this disease more efficiently. Finally, the correct diagnosis of bronchiolitis can be made by considering the most common epidemiological factors such as age, gender, clinical findings laboratory and radiologic signs, and therefore proper diagnosis and appropriate. 
Annals of International Medical and Dental Research

E-ISSN: 2395-2822 | P-ISSN: 2395-2814

Vol-8, Issue-1 | January-February 2022

DOI: 10.53339/aimdr.2022.8.1.40

Page no- 318-324 | Section- Research Article (Paediatrics)

\section{REFERENCES}

1. American Academy of Pediatrics Subcommittee on Diagnosis and Management of Bronchiolitis. Diagnosis and management of bronchiolitis. Pediatrics. 2006;118(4):1774-93. doi: 10.1542/peds.2006-2223.

2. Henderson FW, Clyde WA Jr, Collier AM, Denny FW, Senior RJ, Sheaffer CI, et al. The etiologic and epidemiologic spectrum of bronchiolitis in pediatric practice. J Pediatr. 1979;95(2):183-90. doi: 10.1016/s00223476(79)80647-2.

3. Glezen P, Denny FW. Epidemiology of acute lower respiratory disease in children. $\mathrm{N}$ Engl J Med. 1973;288(10):498-505. doi: 10.1056/NEJM197303082881005.

4. Kabir AR, Mollah AH, Anwar KS, Rahman AK, Amin R, Rahman ME. Management of bronchiolitis without antibiotics: a multicentre randomized control trial in Bangladesh. Acta Paediatr. 2009;98(10):1593-9. doi: 10.1111/j.1651-2227.2009.01389.x.

5. Borchers AT, Chang C, Gershwin ME, Gershwin LJ. Respiratory syncytial virus--a comprehensive review. Clin Rev Allergy Immunol. 2013;45(3):331-379. doi:10.1007/s12016-013-8368-9

6. Smith DK, Seales S, Budzik C. Respiratory syncytial virus bronchiolitis in children. Am Fam Physician. 2017;95(2):2017.

7. Iqbal SM. Management of acute viral bronchiolitis in children: Evidence beyond guidelines. Sudan J Paediatr. 2012;12(1):40-48.

8. Ralston SL, Lieberthal AS, Meissner HC, Alverson BK, Baley JE, Gadomski AM, et al; American Academy of Pediatrics. Clinical practice guideline: the diagnosis, management, and prevention of bronchiolitis. Pediatrics. 2014;134(5):e1474-502. doi: 10.1542/peds.2014-2742.

9. Kuzik BA. Maybe there is no such thing as bronchiolitis. CMAJ. 2016;188(5):351-354. doi:10.1503/cmaj.150683

10. Øymar K, Skjerven HO, Mikalsen IB. Acute bronchiolitis in infants, a review. Scand J Trauma Resusc Emerg Med. 2014;22:23. doi: 10.1186/1757-7241-22-23.

11. Lakhanpaul M, MacFaul R, Werneke U, Armon K, Hemingway $\mathrm{P}$, Stephenson T. An evidence-based guideline for children presenting with acute breathing difficulty. Emerg Med J. 2009;26(12):850-3. doi: 10.1136/emj.2008.064279.

12. Kabir ML, Haq N, Hoque M, Ahmed F, Amin R, Hossain A, et al. Evaluation of hospitalized infants and young children with bronchiolitis - a multi centre study. Mymensingh Med J. 2003 Jul;12(2):128-33.

13. Welliver TP, Reed JL, Welliver RC Sr. Respiratory syncytial virus and influenza virus infections: observations from tissues of fatal infant cases. Pediatr Infect Dis J. 2008;27(10 Suppl):S92-6. doi: 10.1097/INF.0b013e318168b706.

14. Spence L, Barratt N. Respiratory syncytial virus associated with acute respiratory infections in Trinidadian patients. Am J Epidemiol. 1968;88(2):257-66. doi: 10.1093/oxfordjournals.aje.a120884.

15. Yanney M, Vyas H. The treatment of bronchiolitis. Arch Dis Child.2008; 93: 793-8.

16. Henderson FW, Clyde WA Jr, Collier AM, Denny FW, Senior RJ, Sheaffer CI, et al. The etiologic and epidemiologic spectrum of bronchiolitis in pediatric practice. J Pediatr. 1979;95(2):183-90. doi: 10.1016/s00223476(79)80647-2.

17. Glezen P, Denny FW. Epidemiology of acute lower respiratory disease in children. $\mathrm{N}$ Engl J Med. 1973;288(10):498-505. doi: 10.1056/NEJM197303082881005.

18. Simoes EA. Environmental and demographic risk factors for respiratory syncytial virus lower respiratory tract disease. J Pediatr. 2003;143(5 Suppl):S118-26. doi: 10.1067/s0022-3476(03)00511-0.

19. Nguyen SN, Nguyen TNT, Vu LT, Nguyen TD. Clinical Epidemiological Characteristics and Risk Factors for Severe Bronchiolitis Caused by Respiratory Syncytial Virus in Vietnamese Children. Int J Pediatr. 2021;2021:9704666. doi: 10.1155/2021/9704666.

20. Singh C, Angurana SK, Bora I, Jain N, Kaur K, Sarkar S. Clinico demographic profiling of the Respiratory syncytial virus (RSV) infected children admitted in tertiary care hospital in North India. J Family Med Prim Care. 2021;10(5):1975-1980. doi: 10.4103/jfmpc.jfmpc_2406_20.

21. Schroeder AR, Mansbach JM. Recent evidence on the management of bronchiolitis. Curr Opin Pediatr. 2014;26(3):328-333. doi:10.1097/MOP.0000000000000090

22. Singh C, Angurana SK, Bora I, Jain N, Kaur K, Sarkar S. Clinico demographic profiling of the Respiratory syncytial virus (RSV) infected children admitted in tertiary care hospital in North India. J Family Med Prim Care. 2021;10(5):1975-1980. doi:10.4103/jfmpc.jfmpc_2406_20.

Source of Support: Nil, Conflict of Interest: None declare 